\title{
18. LATE PLEISTOCENE PERIODICITIES OF OXYGEN ISOTOPE RATIOS, CALCIUM CARBONATE CONTENTS, AND MAGNETIC SUSCEPTIBILITIES OF WESTERN ARABIAN SEA MARGIN HOLE 728A 1
}

\author{
Tineke N.F. Steens, ${ }^{2}$ Dick Kroon, ${ }^{2,}{ }^{3}$ Warner G. ten Kate, ${ }^{2}$ and Antoinette Sprenger ${ }^{2}$
}

\begin{abstract}
High resolution stratigraphy based on oxygen isotope ratios of the planktonic foraminifers Neogloboquadrina dutertrei (d'Orbigny), Globigeriniodes ruber (d'Orbigny), and Globigerina bulloides (d'Orbigny), magnetic susceptibility, and calcium carbonate content covers the sedimentary record of ODP Hole 728A drilled on the Oman Margin from approximately $10 \mathrm{k}$.y. to $525 \mathrm{k} . \mathrm{y}$., comprising isotopic stages 1-13. Below stage 13 isotopic stage boundaries cannot be defined with certainty in our data. Sediment accumulation rates were calculated from the isotopic record of $N$. dutertrei by matching it with the age model SPECMAP curve. During the glacial periods sediment accumulation rates were higher than during the interglacial periods, reflecting increased input from the shelf during low-stands of sea level and increased eolian input. Periodograms for the past 524 k.y. on oxygen isotope records of $N$. dutertrei, G. ruber, and $G$. bulloides, on calcium carbonate content, magnetic susceptibility, and on a foraminiferal fragmentation record show powers matching the Milankovitch periodicities. High powers are concentrated around $103 \mathrm{k} . \mathrm{y}$. In the spectra of oxygen isotope ratios of $N$. dutertrei, magnetic susceptibility, and foraminiferal fragmentation these are significant at the $80 \%$ confidence level with respect to a first order autoregressive model. Power concentrations near 43 k.y., matching obliquity, are present but subdued in all spectra. Power concentrations near 23 k.y., matching precession, are significant in the spectra of the oxygen isotope record of $N$. dutertrei, magnetic susceptibility, and calcium carbonate content record.

Fragmentation of planktonic foraminifers increased during the interglacial periods. This is attributed to dissolution of the tests in an expanded oxygen minimum zone (OMZ), where undersaturation of calcium carbonate is caused by enhanced production in the euphotic zone, which would suggest stronger monsoonal induced upwelling during interglacial periods. Extension of the OMZ could also be increased by outflow of low oxygen marginal basin bottom water.
\end{abstract}

\section{INTRODUCTION}

The major objective of ODP Leg 117 was to reconstruct the history of the Indian Ocean monsoonal system as recorded in sediments of the western Arabian Sea, and to identify its environmental effects. The monsoonal winds change seasonally in direction, and are forced by summer heating and winter cooling of the Asian continent, resulting in a winter high-pressure cell and a summer low-pressure cell above the Tibetan Plateau. During winter on the northern hemisphere near-surface winds blow from Asia over the Arabian Sea, whereas during summer, wind direction is reversed (for an overview, see Shipboard Scientific Party (1989a) and references cited therein). In summer the southwesterlies blow parallel to the coast of Oman, and Eckman transport causes offshore flow of surface waters. These are replenished by nutrient-rich, oxygen poor, cold waters from deeper levels (Currie et al., 1973; Wyrtki, 1973; Bruce, 1974; Hastenrath and Lamb, 1979). Variations in the intensity of this summer upwelling have a profound effect on the nutrient content, productivity, sea surface water temperatures, oxygen minimum zone, and other chemical, physical, and biological oceanographic factors (Wyrtki, 1971).

Hole $728 \mathrm{~A}$ has been drilled on the continental margin of Oman located at $17^{\circ} 40.790^{\prime} \mathrm{N}$ latitude and $57^{\circ} 49.553^{\prime} \mathrm{E}$ longitude at a water depth of $1428 \mathrm{~m}$ (Fig. 1, Shipboard Scientific Party, 1989a). Since this upper slope hole is situated below the upwelling zone, it provides the possibility to study past environ-

\footnotetext{
${ }^{1}$ Prell, W. L., Niitsuma, N., et al., 1991. Proc. ODP, Sci. Results, 117: College Station, TX (Ocean Drilling Program).

2 Geomarine Center, Institute of Earth Sciences, Free University, De Boelelaan 1085, NL 1081 HV Amsterdam, The Netherlands.

${ }^{3}$ Present address: University of Edinburgh, Grant Institute of Geology, West Mains Road, Edinburgh EH9 3JW, Scotland.
}

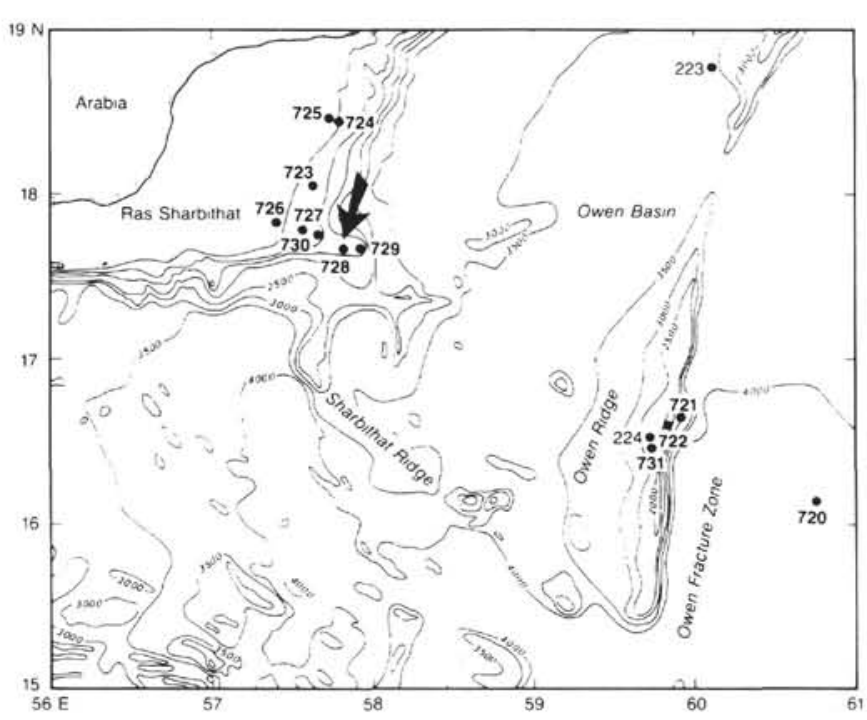

Figure 1. Bathymetry of the Oman margin and the location of ODP Site $72817^{\circ} 40.790^{\prime} \mathrm{N}, 57^{\circ} 49.553^{\prime} \mathrm{E}$ (water depth $1427.8 \mathrm{~m}$ ). From Shipboard Scientific Party (1989c).

mental fluctuations linked with upwelling that may be related with variations in the northern Indian Ocean monsoon system.

Prell and Kutzbach (1987) deduced from modeling and observations of the late Pleistocene sedimentary record that variations in the seasonal distribution of solar radiation, induced by changes in the earth's orbital parameters, forced the monsoon system. This external forcing of the monsoonal-climate system during the past 150 k.y. expresses itself in the well-known Milankovitch periodicities. The influence of the southwestern mon- 
soon increased during interglacial periods and coincides with maxima in summer solar radiation caused by precession.

Site 728 provides a long time record to study the nature of periodicities in the past. The recovered sediments range in age from late Miocene to Pleistocene (Shipboard Scientific Party, 1989a). This study focuses on the late Pleistocene marly-foraminifer-nannofossil ooze. We report on the records of oxygen isotope ratios of three foraminiferal species, calcium-carbonate content, and volume magnetic susceptibility and their respective power spectra, and present preliminary results on percentage counts of some foraminiferal species and a fragmentation record of their tests.

\section{MATERIAL AND METHODS}

All cores of Hole 728A were sampled at intervals of $25 \mathrm{~cm}$ for stable isotope analysis and calcium-carbonate content. On average core recovery was $100 \%$. The volume magnetic susceptibility was determined on board ship at intervals of 6-8 cm (for methods, see Shipboard Scientific Party, 1989c). Figure 2 shows

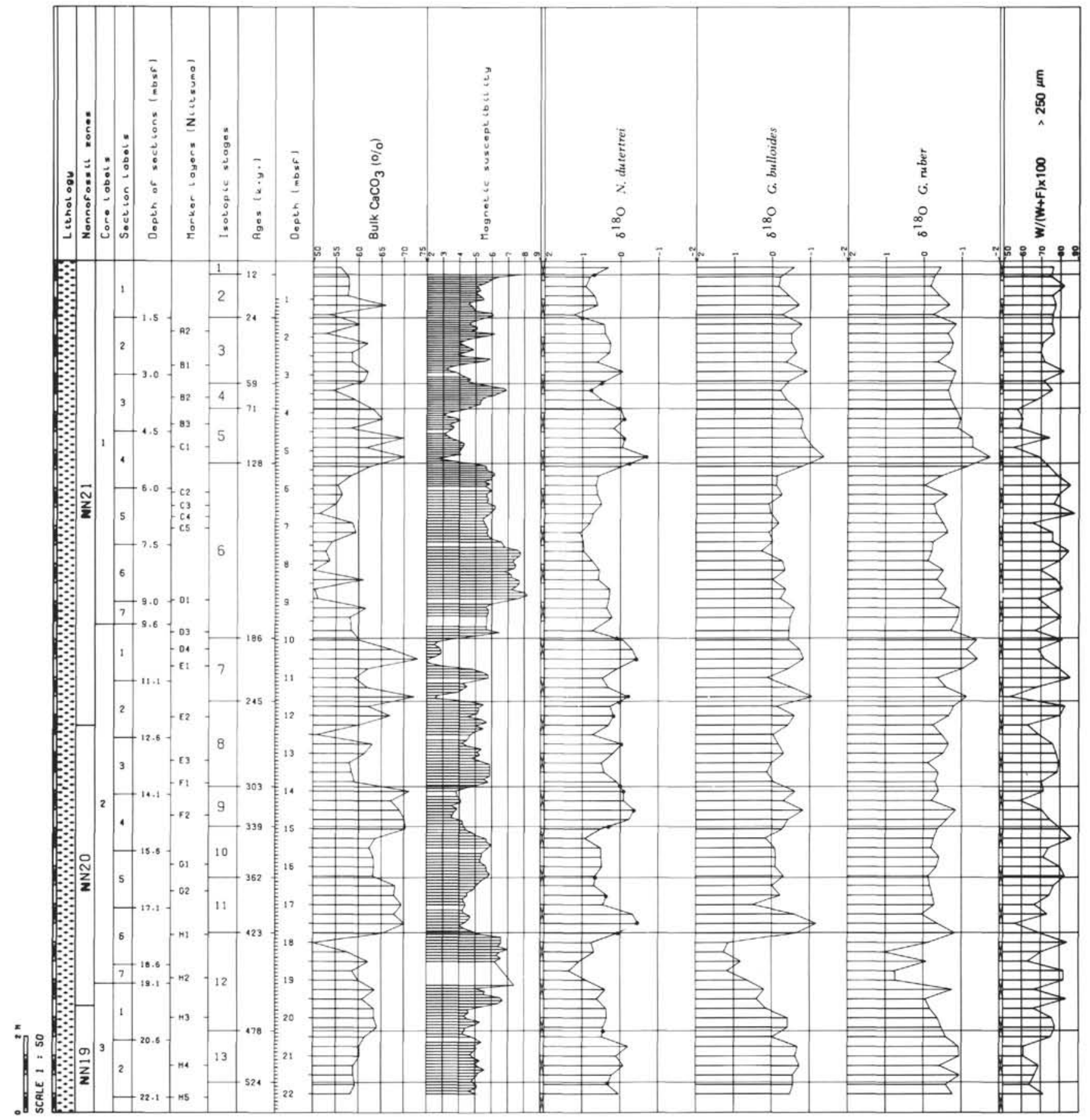

Figure 2. Overview of data in depth domain. Note periodicities in all records which are expressed in the power spectra of Figure 5. Correlation points used for matching the $\delta^{18} \mathrm{O}$ record of $N$. dutertrei with the SPECMAP curve are given. 
a graphical overview of pertinent data prepared with program STRATCOLUMN (Sprenger and ten Kate, 1990).

The calcium-carbonate content of the samples was determined coulometrically. Samples were shaken with $7.5 \% \mathrm{HCl}$ and escaping $\mathrm{CO}_{2}$ was trapped in a gasometer. All measurements were done at room temperature and 1 atmosphere. The results were calibrated with a standard solution of sodium carbonate. Reproducibility is within $2.5 \%$ of the measured values.

To obtain foraminiferal tests the samples were washed over a $60 \mu \mathrm{m}$ sieve and the residues were dried at $50^{\circ} \mathrm{C}$. Relative percentage counts on planktonic foraminifers were made in the $125-250 \mu \mathrm{m}$ and $>250 \mu \mathrm{m}$ fractions. Fifty specimens of $N$. $d u-$ tertrei in the $>250 \mu \mathrm{m}$ fraction, 60 specimens of $G$. ruber, and 120 specimens of $G$. bulloides in the 125-250 $\mu$ m fraction were picked for stable isotope analysis. The tests were ultrasonically cleaned for $2 \mathrm{~min}$ in analytical grade methanol. The carbonate was dissolved in $100 \%$ phosphoric acid under vacuum at $50^{\circ} \mathrm{C}$. Isotopic analyses were performed offline on a MAT 251 mass spectrometer. The results are referred to PDB by the standard notation (Craig, 1957) and are calibrated to the NBS 19 and 20 standard through an intermediate laboratory standard (Merck $100 \%$ calcite). The analytical precision of the "Merck" standard reached during the measurements from working standards was $0.05 \mathrm{~N} \%$ for $\delta^{18} \mathrm{O}$. Reproducibility of duplicate samples was within $0.2 \%$ (Table 1 ).

We matched 25 points of the oxygen stable isotope data of $N$. dutertrei, and the positions of stratigraphic marker layers of Niitsuma (pers. comm.), with the SPECMAP isotope curve (Imbrie et al., 1984) to transform our data linearly from the depth into the time domain (Tables 2 and 3 ). This results in unequally spaced time series. A graphical overview of the data in the time domain is shown in Figure 3, together with the SPECMAP curve. Cubic spline functions were used to create equally spaced time series; the sample intervals are $6 \mathrm{k} . \mathrm{y}$. for $\delta^{18} \mathrm{O} N$. dutertrei, $\delta^{18} \mathrm{O}$ G. bulloides, $\delta^{18} \mathrm{O} G$. ruber, and calcium carbonate content and $2 \mathrm{k}$.y. for magnetic susceptibility. The series do not show linear trends and are corrected for the means only. Stationarity in the wide sense has been assumed. Periodograms are constructed by harmonic analysis and smoothed with a Hanning filter. For comparison, a first order autoregressive process model together with $80 \%$ confidence limits have been added to the smoothed power spectra (ten Kate and Sprenger, 1989).

\section{OXYGEN STABLE ISOTOPES, MAGNETIC SUSCEPTIBILITY RECORD, AND AGE FRAMEWORK}

Because Hole 728A is underlying an upwelling area, the global $\delta^{18} \mathrm{O}$ signal may be considerably disturbed. Nevertheless, isotopic stages could be recognized in the upper $21 \mathrm{~m}$ of the section

Table 1. Reproducibility of duplicate samples for oxygen isotope values.

\begin{tabular}{lcr}
\hline \multicolumn{1}{c}{ Species } & Sample & \multicolumn{1}{c}{$\delta^{18} \mathrm{O}$} \\
\hline$N$. dutertrei & $1-6-90-92$ & 0.58 \\
G. ruber & $1-2-90-92$ & -0.75 \\
& & -0.42 \\
& $1-4-90-92$ & -1.17 \\
& & -0.96 \\
& $1-4-115-117$ & -0.48 \\
& & -0.35 \\
& $2-2-115-117$ & -0.25 \\
& $2-5-90-92$ & -0.26 \\
& & -0.17 \\
& $3-5-2-4$ & -0.13 \\
& & -0.36 \\
\hline
\end{tabular}

Table 2. Summary of pertinent numerical data in depth domain. Core, section, and interval of the samples, depth, oxygen isotope ratios $(\% 0)$ of $\mathrm{N}$. dutertrei, G. bulloides, and G. ruber, and bulk $\mathrm{CaCO}_{3}$ percentages from samples in the uppermost part of Hole 728A.

\begin{tabular}{|c|c|c|c|c|c|}
\hline $\begin{array}{l}\text { Sample } \\
\text { number }\end{array}$ & $\begin{array}{l}\text { Depth } \\
\text { (mbsf) }\end{array}$ & a & b & c & d \\
\hline$-15-17$ & 0.16 & 0.33 & -0.58 & -0.45 & 56.0 \\
\hline $1-1-40-42$ & 0.41 & 0.81 & -0.22 & -0.28 & 57.8 \\
\hline $1-1-65-67$ & 0.66 & 0.92 & -0.17 & -0.18 & 57.9 \\
\hline $1-1-90-92$ & 0.91 & 0.69 & -0.44 & -0.41 & 57.6 \\
\hline $1-1-115-117$ & 1.16 & 0.61 & -0.71 & -0.68 & 66.0 \\
\hline $1-1-140-142$ & 1.41 & 1.22 & -0.27 & -0.26 & 53.9 \\
\hline $1-2-15-17$ & 1.66 & 0.43 & -0.79 & -0.86 & 60.3 \\
\hline $1-2-40-42$ & 1.91 & 0.40 & -0.52 & -0.64 & 53.0 \\
\hline $1-2-65-67$ & 2.16 & 0.26 & -0.52 & -0.78 & 62.1 \\
\hline $1-2-90-92$ & 2.41 & 0.29 & -0 & -0.69 & 58.6 \\
\hline $1-2-115-117$ & 2.66 & 0.62 & -0.37 & -0.37 & 58.6 \\
\hline $1-2-140-142$ & 2.91 & -0.06 & -0 & -0.85 & 62.1 \\
\hline $1-3-15-17$ & 3.16 & 0.40 & -0.45 & -0.75 & 61.2 \\
\hline $1-3-40-42$ & 3.41 & 0.80 & -0 & -0.65 & 54.5 \\
\hline & 3.66 & 0.49 & -0.38 & -0.72 & 59.3 \\
\hline $1-3-90-92$ & 3.91 & 0.00 & -0 & -0 & 63.2 \\
\hline $1-3-115-117$ & 4.16 & -0.11 & -0.82 & -0.98 & 65.3 \\
\hline $1-3-140-142$ & 4.41 & 0.17 & -0.77 & -0.91 & 58.4 \\
\hline $1-4-1$ & 4.66 & -0.12 & -0 & -1.30 & 69.9 \\
\hline $1-4-40-42$ & 4.91 & -0.05 & -1.09 & -1.30 & 61.7 \\
\hline $1-4-65-67$ & 5.16 & -0.71 & -1.37 & -1.76 & 70.2 \\
\hline $1-4-90-92$ & 5.41 & -0.04 & -0.79 & -1.17 & 62.5 \\
\hline $1-4-115-11$ & 5.66 & 0.58 & -0.14 & -0.48 & 58.3 \\
\hline $1-4-140-142$ & 5.91 & 0.64 & -0.12 & -0.03 & 55.4 \\
\hline & 6.16 & 0.60 & -0.27 & -0.63 & 56.4 \\
\hline $1-5-40-42$ & 6.41 & 0.50 & 0.08 & -0.28 & 55.0 \\
\hline $1-5-65-67$ & 6.66 & 0.72 & 0.03 & -0.35 & 51.4 \\
\hline $1-5-90-92$ & 6.91 & 0.79 & -0.19 & -0.53 & 58.7 \\
\hline & 7.1 & $1 . C$ & 0.07 & -0.65 & 59.4 \\
\hline $1-5-140-142$ & 7.41 & 0.97 & -0.03 & -0.26 & 54.2 \\
\hline $1-6-15-17$ & 7.6 & 0.96 & 027 & -023 & 52.8 \\
\hline $1-6-40-42$ & 7.91 & 0.74 & -0.28 & -0.12 & 53.7 \\
\hline & 8.16 & 0.55 & -0.35 & -0.53 & 50.1 \\
\hline $1-6-90-5$ & 8.41 & 0.5 & -0 & -0.36 & 61.1 \\
\hline & & & -0 & -0.61 & 50.3 \\
\hline $1-6-140-14$ & 8.91 & 0.30 & -0.23 & -0.45 & 51.0 \\
\hline $1-7-15-17$ & & & & & 61.6 \\
\hline $1-7-40-42$ & 9.41 & 0.22 & -0 & -0.91 & 58.1 \\
\hline & & 0. & & & 58.5 \\
\hline $2-1-40-42$ & 10.01 & -0.08 & -0 & -1.41 & 60.3 \\
\hline & & -0.32 & & 5 & 67.4 \\
\hline $2-1-90-9$ & 51 & -0.44 & -0.84 & -1.43 & 73.1 \\
\hline $2-1-115-11$ & & & -0 & & 62.1 \\
\hline $2-1-140+2$ & & & & -0 & 9.2 \\
\hline & & & -0 & & 51.9 \\
\hline$-2-40-4$ & 1 & -0. & -1 & -1.14 & 2.3 \\
\hline $2-2-65-6$ & 76 & & -0 & & 2.1 \\
\hline $2=000$ & 12.01 & & -0 & $-c$ & 6.9 \\
\hline $2-2$ & & & -0 & & 9.9 \\
\hline 2,40 & 12 & & -0 & -0 & 50.9 \\
\hline $2-3-15-17$ & & -0.05 & -0 & & 3.1 \\
\hline $2-3-40-42$ & 201 & 0.19 & -0.32 & -0 & 1.3 \\
\hline $2-3-65-6$ & & & & & 8.0 \\
\hline & 1 & & & & 8.5 \\
\hline 2-3-115 & & & 5 & & 59.1 \\
\hline $1-3,140$ & 1 & 0 & & & 71.2 \\
\hline $2-4-15-17$ & & -0 . & -0 & & 67.1 \\
\hline $2-40-40$ & & & & & \\
\hline $2-4-6$ & & & -0 & & 0.1 \\
\hline & & & & & \\
\hline & & & & & 63.7 \\
\hline $2-4-14$ & & & & & \\
\hline & & & -0 & & 63.3 \\
\hline & & & & & \\
\hline & & & -0 & & 63.2 \\
\hline & & & & & \\
\hline $2-5-115-11$ & & & -0 & & 67.8 \\
\hline & & & & & \\
\hline $2-6-15-1$ & & -0. & -0.60 & 0.05 & 67.8 \\
\hline & & -0.4 & -1.17 & & 70.1 \\
\hline & & 0. & -0.64 & & 65.2 \\
\hline 2-6-90-92 & 18.01 & 0.75 & 1.14 & -0.14 & 50.2 \\
\hline
\end{tabular}


Table 2 (continued).

\begin{tabular}{lrrrrr}
\hline $\begin{array}{l}\text { Sample } \\
\text { number }\end{array}$ & $\begin{array}{l}\text { Depth } \\
\text { (mbsf) }\end{array}$ & a & b & c & d \\
\hline $2-6-115-117$ & 18.26 & 0.68 & 1.26 & 1.02 & 57.6 \\
$2-6-140-142$ & 18.51 & 1.07 & 0.81 & -0.09 & 62.2 \\
$2-7-15-17$ & 18.76 & 1.34 & 1.17 & 0.75 & 58.6 \\
$2-7-40-42$ & 19.01 & 0.89 & 0.65 & 0.73 & 60.0 \\
$3-1-15-17$ & 19.26 & 0.39 & 0.19 & -0.76 & 63.6 \\
$3-1-40-42$ & 19.51 & 0.61 & 0.40 & -0.05 & 60.8 \\
$3-1-65-67$ & 19.76 & 0.37 & 0.15 & -0.17 & 63.4 \\
$3-1-90-92$ & 20.01 & 0.35 & -0.43 & -0.37 & 63.4 \\
$3-1-115-117$ & 20.26 & 0.45 & -0.42 & -0.47 & 64.1 \\
$3-1-140-142$ & 20.51 & 0.48 & -0.01 & -0.59 & 61.3 \\
$3-2-15-17$ & 20.76 & -0.22 & -0.69 & -0.93 & 60.2 \\
$3-2-40-42$ & 21.01 & 0.10 & -0.63 & -0.95 & 60.3 \\
$3-2-65-67$ & 21.26 & -0.09 & -0.74 & -0.43 & 58.9 \\
$3-2-90-92$ & 21.51 & 0.22 & -0.56 & -0.96 & 58.9 \\
$3-2-115-117$ & 21.76 & 0.33 & -0.57 & -0.59 & 59.3 \\
$3-2-140-142$ & 22.01 & 0.03 & -0.49 & -0.77 & 58.3 \\
\hline
\end{tabular}

$\mathrm{a}=\delta^{18} \mathrm{O} N$. dutertre

$\mathrm{b}=\delta^{18} \mathrm{O} \mathrm{G}$. bulloides

$\mathrm{c}=\delta^{18} \mathrm{O} G$. ruber

$\mathrm{d}=\mathrm{CaCO}_{3} \%$

Table 3. List of data, used to construct the timedepth relationships. Depth, age, and events (SPECMAP) of the points used to visually match the $\delta^{18} \mathrm{O}$ profile of $N$. dutertrei with the SPECMAP curve (Imbrie et al., 1984).

\begin{tabular}{rrr}
\hline $\begin{array}{c}\text { Age } \\
\text { (k.y.) }\end{array}$ & $\begin{array}{r}\text { Depth } \\
\text { (mbsf) }\end{array}$ & Event \\
\hline 12 & 0.35 & 2.0 \\
24 & 1.49 & 3.0 \\
59 & 3.23 & 4.0 \\
64 & 3.41 & 4.2 \\
71 & 3.89 & 5.0 \\
80 & 4.07 & 5.1 \\
100 & 4.66 & 5.3 \\
122 & 5.21 & 5.5 \\
128 & 5.33 & 6.0 \\
186 & 9.96 & 7.0 \\
216 & 10.53 & 7.3 \\
238 & 11.55 & 7.5 \\
245 & 11.63 & 8.0 \\
250 & 11.71 & 8.2 \\
286 & 12.76 & 8.5 \\
303 & 13.89 & 9.0 \\
310 & 14.09 & 9.1 \\
330 & 14.71 & 9.3 \\
339 & 14.95 & 10.0 \\
362 & 16.30 & 11.0 \\
368 & 16.76 & 11.1 \\
405 & 17.55 & 11.3 \\
423 & 17.75 & 12.0 \\
478 & 20.35 & 13.0 \\
524 & 21.70 & 14.0 \\
\hline & & \\
\hline
\end{tabular}

(Figs. 2 and 3). To approximate the position of the isotopic stage boundaries in this interval, the local Hole $728 \mathrm{~A}$ curve for $\delta^{18} \mathrm{O} N$. dutertrei was visually matched with the stacked SPECMAP curve (Imbrie et al., 1984) (Figs. 2 and 3 and Table 3). A similar signal with distinct periodicities could be recognized in the volume magnetic susceptibility depth profile for the same section, although there may be a phase lag between the two signals.

Below isotopic stage 13, the oxygen isotope record can no longer be matched with the SPECMAP curve. For the upper part of the section, sediment accumulation rates are estimated using the isotopic events of Prell et al. (1986) and the corresponding ages as defined by Imbrie et al. (1984). Average accu- mulation rates were considerably higher during glacial stages 2 , $4,6,8,10$, and 12 than during the interglacial stages (Fig. 4). This could be the effect of low-stands of sea level during which a higher input of terrigenous material occurred. The exposed shelf area is enlarged, enhancing transport in the nepheloid layer (Sirocko and Sarnthein, 1989), and input of eolian dust which also increased due to greater overall aridity on the continent (Clemens and Prell, this volume). The volume magnetic susceptibility profile shows a similar trend (Figs. 2 and 3 ). Increased input of magnetic particles results in higher magnetic susceptibility of the sediment if the influx of other particles, such as biogenic carbonate or silicious skeletal fragments, remained more or less constant. Dilution by terrigenous input also explains why the carbonate content profile forms a near mirror image of the volume magnetic susceptibility profile in this part of the section (Figs. 2 and 3).

\section{SPECTRAL ANALYSES}

In Figure 5A a smoothed periodogram of the summed normalized values of the Earth's orbital parameters (Berger, 1978) calculated at intervals of 2 k.y. is presented for the latitude of Hole 728. This periodogram shows the quasi-periodicities of the Milankovitch model; a small peak at 105 k.y. associated with the short cycle of eccentricity of the Earth's orbit, a peak at 41 k.y. associated with the obliquity of the Earth's axis and two peaks at 23 and 19 k.y. associated with the precession of the Earth's axis. A periodogram of the SPECMAP age model sampled at 2 k.y. intervals (Fig. 5B; Imbrie et al., 1984) shows the peaks to be expected from geological proxy data. A high power concentration is present at $105 \mathrm{k} . \mathrm{y}$. and smaller peaks are found at 41,23 , and 19 k.y.

Figures $5 \mathrm{C}-5 \mathrm{E}$ show periodograms of the $\delta^{18} \mathrm{O}$ data of three different foraminiferal species from Hole 728A. In the spectrum of $N$. dutertrei $\delta^{18} \mathrm{O}$ values (Fig. $5 \mathrm{C}$ ), two peaks are significant at the $80 \%$ confidence level, one around $103 \mathrm{k} . \mathrm{y}$., and another around $22 \mathrm{k} . \mathrm{y}$. A peak around $43 \mathrm{k} . \mathrm{y}$. is present, although not significant. Figures $5 \mathrm{D}$ and $5 \mathrm{E}$ show the periodograms of the $\delta^{18} \mathrm{O}$ records of $G$. bulloides and $G$. ruber. In the spectrum of $G$. bulloides (Fig. 5D) only one peak is significant around 86 k.y. In the spectrum of $G$. ruber (Fig. 5E) no significant peaks are found, however, the spectrum reveals small peaks matching the Milankovitch quasi-periodicities.

Figure $5 \mathrm{~F}$ presents a periodogram of the magnetic susceptibility record with two significant power concentrations, one around 103 k.y., and another around 23 k.y. Figure 5G shows the spectrum of the calcium carbonate percentage record with one significant peak around $23 \mathrm{k} . \mathrm{y}$.

The spectrum of the foraminiferal fragmentation record from the $>250 \mu \mathrm{m}$ fraction (Fig. $5 \mathrm{H}$ ) has two significant peaks, one around 103 k.y. and another around 34 k.y.

$N$. dutertrei is a thermocline dweller (Brummer and Kroon, 1988 ) and the spectrum on the $\delta^{18} \mathrm{O}$ values of this species seems to reflect the global climate signal as was found in the SPECMAP model (Fig. 5B). G. bulloides and G. ruber are both surface dwelling species, with this difference that $G$. bulloides blooms especially during the upwelling season, while $G$. ruber lives in the surface waters all year round. The spectra of these $\delta^{18} \mathrm{O}$ records differ from that of $N$. dutertrei and probably reflect a local signal.

The magnetic susceptibility record mainly reflects the terrigenous influx. From the spectra we conclude that two mechanisms influence this influx: we associate the high powers around 103 k.y. with sea-level high and low-stands, related to the global ice volume, and the power concentration around $23 \mathrm{k} . \mathrm{y}$. with the varying influx of wind born particles, the amount of which depends on the monsoonal strength. 


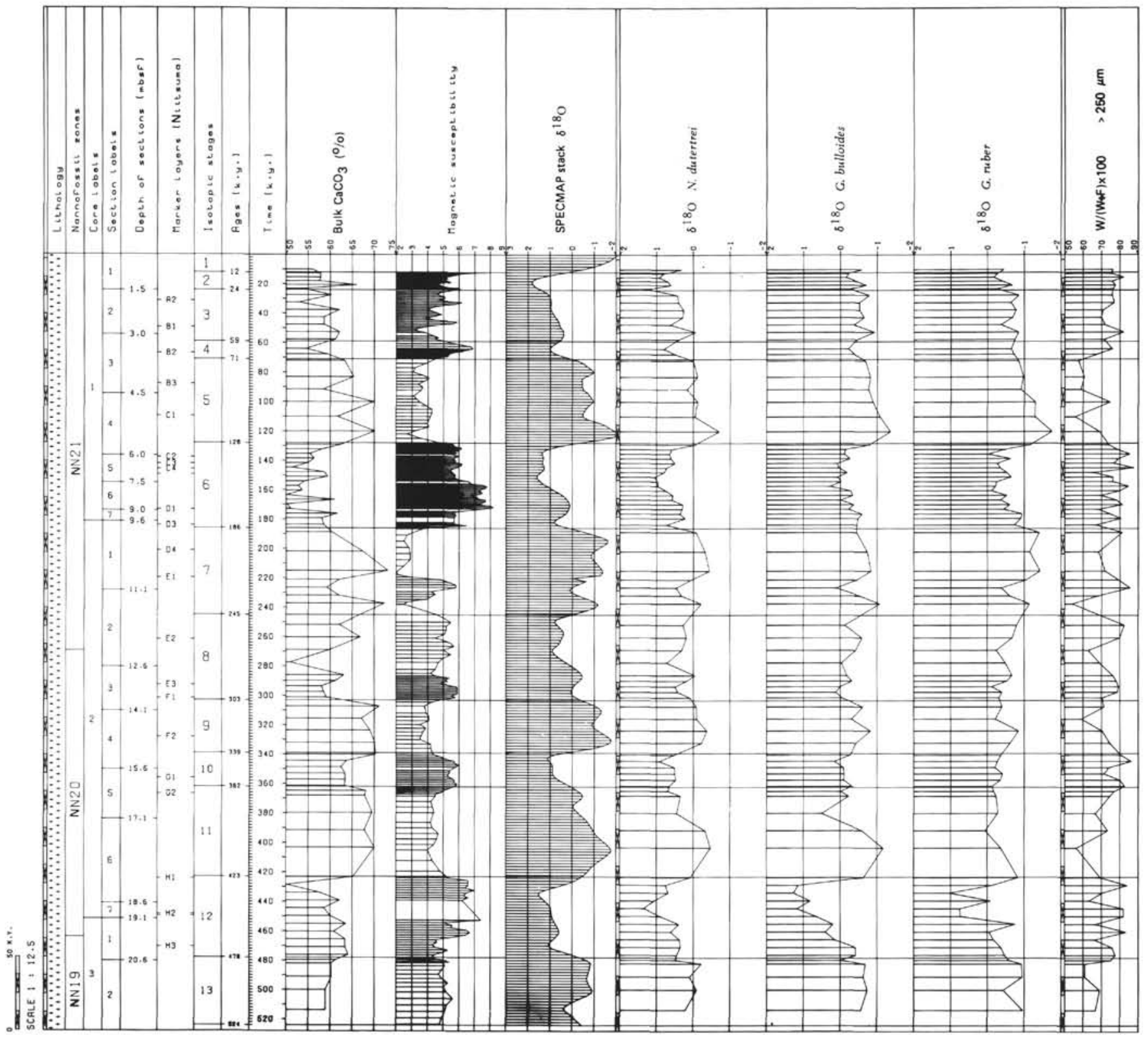

Figure 3. Overview of data in time domain. Correlation between SPECMAP curve and our data was made with help of $\delta^{18} \mathrm{O} N$. dutertrei curve and Niitsuma's marker layers. Note high correlation between magnetic susceptibility record and $\mathrm{CaCO}_{3}$ curve. Differences in sediment accumulation rates are shown in the sample density in the time domain (see also Fig. 4). The overall higher values for $\delta^{18} \mathrm{O}$ in $N$. dutertrei in comparison to the $\delta^{18} \mathrm{O}$ of those in the other two species measured, indicate that $N$. dutertrei is living in colder, deeper waters. Kroon and Ganssen (1989) showed similar relationships in the stable oxygen isotopes of living planktonic foraminiferal faunas in the Arabian Sea. Living $N$. dutertrei has higher $\delta^{18} \mathrm{O}$ values than the expected equilibrium values in surface waters, indicating its deeper habitat (Kroon and Ganssen, pers. comm.). The maximum amplitudes between glacial and interglacial periods in the $\delta^{18} \mathrm{O}$ record of $N$. dutertrei are more pronounced than those of the other two species which are "true" surface dwellers. We ascribe this to temperature effects. The deeper thermocline dweller is driven to the warmer surface waters during enhanced upwelling in the interglacial periods as a function of the intensified southwest monsoonal winds.

\section{FRAGMENTATION RECORD AND SOME PERCENTAGE COUNTS OF PLANKTONIC FORAMINIFERS}

The preservation state of the sediment is related to the isotopic stages and can be estimated by the percentage fragmentation record of foraminiferal tests as defined by (whole tests/ (whole tests + fragments)) $\times 100$. Percentage fragmentation counts (Table 4, Fig. 6) were made in two fractions, 125-250 $\mu \mathrm{m}$ and $>250 \mu \mathrm{m}$. As expected, this record shows a higher variability range $(35 \%-85 \%)$ in the smaller fraction than in the larger fraction $(55 \%-90 \%)$, because the smaller specimens are more sensitive to dissolution (Fig. 6). Low values in the $>250 \mu \mathrm{m}$ fraction occur in isotopic stages $5,7,9$, and 11, during the interglacial periods. A similar pattern was found in the $125-250$ $\mu \mathrm{m}$ fraction, with the exception of stage 7 . Figure 7 shows a $G$. menardii specimen affected by dissolution, illustrating that fragmentation was caused by dissolution and not by mechanical breakdown.

The $G$. bulloides percentage shows maximum values in isotopic stages 3,6 , and 8 in the $>250 \mu$ m fraction while minimum values occur in stages 9 and 11 (Table 4, Fig. 6). From the finer 


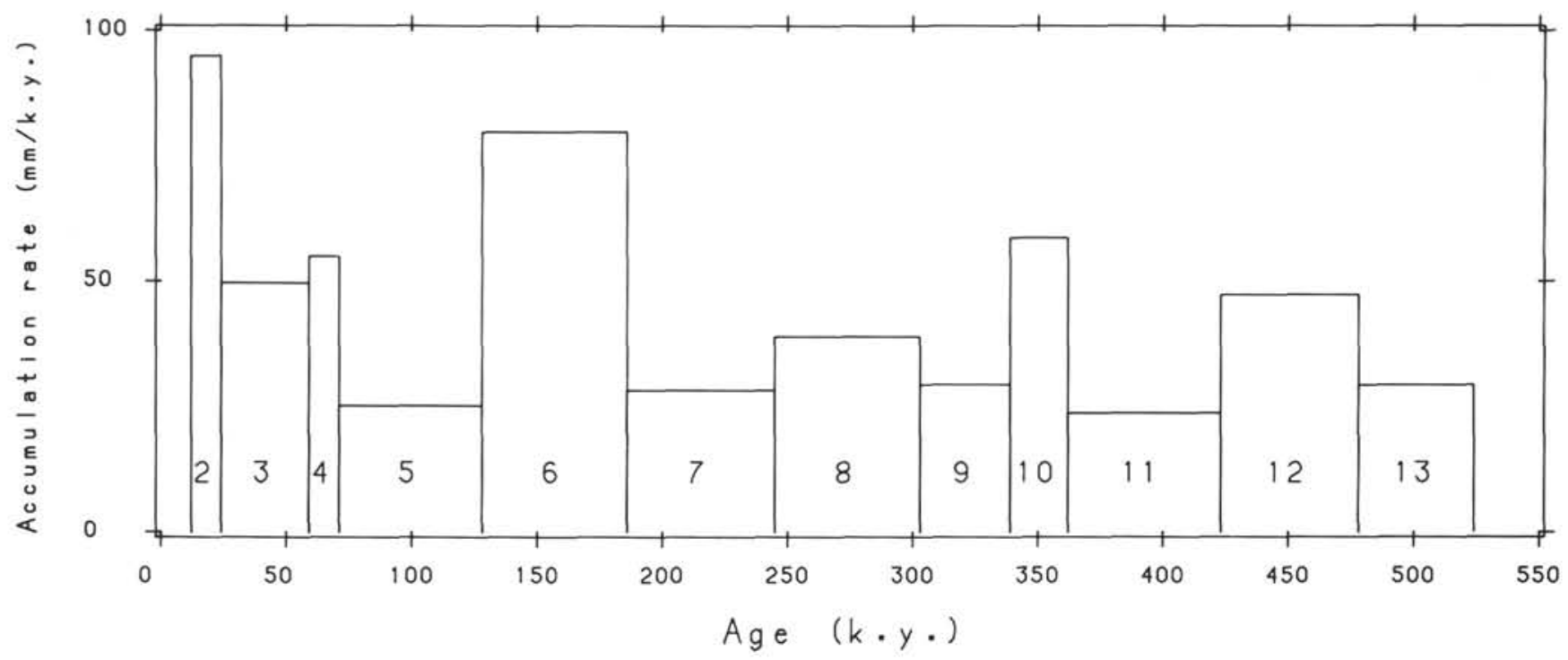

Figure 4. Average sediment accumulation rates in mm/k.y. for the last 524 k.y. in Hole 728A. Note higher sedimentation rates during glacial periods. Isotopic stages are marked by numbers 1-13.

fraction we draw the same conclusion, that there is no obvious relationship between the percentages of $G$. bulloides and the glacial and interglacial periods.

The depth profile of percentage G. menardii in the $>250 \mu \mathrm{m}$ fraction shows high peaks in isotopic stages $5,6,7,9$, and 11 . Also with a tendency for higher values during the interglacial periods.

The dextral coiling Neogloboquadrina pachyderma (Ehrenberg) relative abundance pattern shows low values during isotopic stages 1, 3, 5, 9, and 11 (Table 4, Fig. 6). Therefore, the relative frequencies of this species during interglacial periods are lower than during glacial periods. This signal may be indicative for colder seawater temperatures during glacial periods (ten Haven and Kroon, this volume).

From the above relative distribution patterns we conclude that frequencies of foraminifers in this hole can not be used directly as proxy-indicators of variations in the upwelling system over the time span considered. The fragmentation record and the relative frequency record of $G$. menardii, a species highly resistant to dissolution, indicate that strong dissolution of the tests occurred during the interglacial periods. The abundance record of $G$. bulloides is the result of a miscellaneous signal: a signal of high productivity during interglacial periods is distorted by fragmentation due to strong dissolution.

\section{DISCUSSION AND CONCLUSIONS}

\section{Sediment Accumulation Rates}

Significant variations in sediment accumulation rates were found for the past $524 \mathrm{k}$.y., with relatively low accumulation rates during the interglacial periods compared to the glacial periods. A similar pattern is found in volume magnetic susceptibility depth profile where high values during the low-stands indicate increased input of magnetic particles as compared to other particles like skeletons from biota which lived in the euphotic zone of the sea surface layer. This alternating pattern can be reasonably explained by sea-level changes and fluctuating eolian input, that both have a large impact on sediment distribution. During high sea-level stands, most terrigenous material is trapped on the shelf, whereas during glacial periods this zone is eroded and sedimentation rates are higher in upper slope basins. Increased aridity and less vegetation cover during the glacial pe- riods in the dust-source areas will lead to a greater influx of wind-borne particles.

Below isotopic stage 13, the volume magnetic susceptibility depth profile and the oxygen isotope curve are quite dissimilar, which may indicate that major paleoceanographic or tectonic phenomena occurred prior to $524 \mathrm{k} . \mathrm{y}$., for instance, tectonic movements along adjacent ophiolitic basement blocks that enclose this upper slope basin in a transcurrent fault zone (Mountain and Prell, 1989).

\section{Spectral Analyses}

Despite the fact that Hole 728A is not located in an ideal setting for exploring periodicities associated with monsoonal factors, as explained earlier, an oxygen isotope stratigraphy on $N$. dutertrei could be established for the past $524 \mathrm{k}$.y. Although the intervals which represent the interglacial periods were relatively undersampled for time series analysis, the periodogram closely resembles the spectrum of the SPECMAP age model (Figs. 5B and 5C, Imbrie et al., 1984). The global signal of waxing and waning of ice sheets is expressed as a distinct and dominating power concentration around $103 \mathrm{k} . \mathrm{y}$., and seems to be typical in many late Pleistocene sections (Shackleton and Opdyke, 1973; Pisias and Moore, 1981; Prell, 1983; see also power spectrum SPECMAP curve, Fig. 5B). Obliquity and precession parameters are less pronounced in the spectra, which may be caused by upwelling processes, obscuring the fractionation of isotope ratios, by bioturbation, or by undersampling of the record, especially during the interglacial periods.

In contrast, the volume magnetic susceptibility record was sampled more adequately, on average one sample every $6-8 \mathrm{~cm}$. Its power spectrum shows a precession peak and only a small peak that can be associated with the obliquity parameter. The spectrum of the calcium-carbonate content series shows approximately a similar pattern. This may be related to the position of Hole 728A in the low latitudinal region where variation in obliquity has minor influence on daily insolation (Berger and Pestiaux, 1984). Both spectra show high powers around 103 k.y.

\section{Dissolution and the Oxygen Minimum Zone}

With the established time frame it becomes possible to date paleoceanographic events and/or periodicities in the upper part of the section. This was one of the main objectives of drilling in 
Table 4. Relative percentage records for several species and the fragmentation data for the fractions 125-250 $\mu \mathrm{m}$ and $>250 \mu \mathrm{m}$.

Data ODP Leg 117, Hole 728A

\begin{tabular}{|c|c|c|c|c|c|c|}
\hline Sample & A & B & C & D & E & F \\
\hline $1-1-15-17$ & 24.2 & 21.9 & 1.4 & 1.9 & & 17.0 \\
\hline & 23.0 & 17.6 & & & & 74.6 \\
\hline $1-1-65-67$ & 17.3 & 17.9 & 6.4 & 3.4 & 82.0 & 80.6 \\
\hline $1-1-90-92$ & 24.7 & 20.2 & 9.8 & 3.1 & 75.8 & 72.5 \\
\hline $1-1-115-117$ & 23.0 & 21.4 & 12.5 & 3.7 & 77.6 & 69.0 \\
\hline $1-1-140-142$ & 20.1 & 10.5 & 6.7 & 2.1 & 76.3 & 64.5 \\
\hline $1-2-15-17$ & 26.6 & 21.7 & 8.9 & 0.0 & 75.8 & 61.7 \\
\hline $1-2-40-42$ & 18.1 & 23.2 & 6.2 & 2.2 & 76.9 & 67.1 \\
\hline $1-2-65-67$ & 26.6 & 23.7 & 12.5 & 2.8 & 70.9 & 63.3 \\
\hline $1-2-90-92$ & 26.5 & 21.3 & 13.0 & & & 64.9 \\
\hline $1-2-115-117$ & & 31.4 & & & & 68.0 \\
\hline $1-2-140-142$ & 22.5 & 25.4 & & & & 70.4 \\
\hline $1-3-15-17$ & 22.7 & 27.5 & 7.9 & 4.3 & 71.4 & 64.1 \\
\hline $1-3-40-42$ & 10.5 & 25.8 & 6.8 & 7.7 & 75.8 & 69.9 \\
\hline $1-3-65-67$ & 9.8 & 22.9 & 18.4 & 2.7 & 67.6 & 69.4 \\
\hline $1-3-90-92$ & 18.2 & 32.7 & 18.5 & 1.8 & 57.5 & 61.7 \\
\hline $1-3-115-117$ & 25.8 & 30.4 & 10.8 & 2.3 & 60.6 & 59.9 \\
\hline $1-3-140-142$ & 15.5 & 33.5 & 17. & 1.0 & 58.8 & 61.7 \\
\hline $1-4-15-17$ & 21.1 & 32.2 & 12. & & & 64.5 \\
\hline $1-4-40-42$ & 26.0 & 14.9 & 15 & & & 39.4 \\
\hline $1-4-65$ & 8.5 & & & & & 57.8 \\
\hline & & & & & & 6.2 \\
\hline & & & & & & 4.7 \\
\hline $1-4$ & & & & & & 2.5 \\
\hline & 28.5 & 32.2 & 11. & 3. & 79 & 80.0 \\
\hline & 24.5 & 28.8 & 7. & 1.5 & 76.9 & 78.1 \\
\hline $1-5$ & 25.1 & 19.6 & 22. & 5.1 & 87.6 & 72.5 \\
\hline $1-5-9$ & 23.1 & 24.3 & 12. & 1.6 & & 63.3 \\
\hline $1-5-115-117$ & 11.2 & 16.3 & 8 & 7.3 & 76.3 & 62.5 \\
\hline $1-5-140-142$ & 20.2 & 25.7 & 4 & 6.4 & & 71.4 \\
\hline $1-6-15-17$ & 13.2 & 16.4 & 1 & 9.3 & & 69.0 \\
\hline $1-6-40-42$ & & & & & & 3.5 \\
\hline $1-6-6$ & & & & & & 9.0 \\
\hline & & & & & & 9.4 \\
\hline & & & & & & 69.0 \\
\hline $1-6-1$ & 15.5 & 23.9 & 4.5 & 5.4 & & 60.6 \\
\hline $1-7-15-17$ & 31.7 & 33.6 & 12.0 & 7.7 & 74.6 & 68.0 \\
\hline $1-7-40-42$ & 32.9 & 27.3 & 32 & 4.3 & 80.6 & 63.7 \\
\hline $2-1-15-17$ & 12.6 & 21.4 & 16. & 7.9 & 67 & 51.0 \\
\hline $2-1-40-42$ & 26.0 & 40.2 & 13.4 & 4.8 & 81.3 & 80.6 \\
\hline $2-1-65-67$ & 17.0 & 29.3 & 22 . & 2.4 & & 8.5 \\
\hline $2-1-90-92$ & & 29 & 19 & 2.9 & & 8.0 \\
\hline & & & & & & 8.0 \\
\hline & & & & & & 9.9 \\
\hline $2-2-15-17$ & 7.9 & 20 . & 1 & 6. & 68 & 59.2 \\
\hline $2-2-40-42$ & 11.1 & 22.2 & 19. & 5.1 & 54.1 & 56.8 \\
\hline $2-2-65-67$ & 18.0 & 27.2 & 5 & 4.3 & 82.6 & 70.9 \\
\hline $2-2-90-92$ & 11.3 & 26.1 & 19.1 & 5.0 & 800 & 73.0 \\
\hline $2-2-115-11$ & 22.4 & 24.8 & 19.3 & 7.0 & & 59.2 \\
\hline $2-2-140-142$ & 21.5 & 21.3 & 9.3 & 7.9 & 69.0 & 59. \\
\hline $2-3-15-17$ & 34.2 & 28.3 & 6.3 & 8.4 & 76.3 & 3. \\
\hline $2-3-40-42$ & 21.5 & 34.6 & 12 & 7.4 & 7 & 9.5 \\
\hline & & & & & & 9.4 \\
\hline & & & & & & 6.2 \\
\hline $2-3-1$ & 10.2 & 16.9 & 14.9 & 8.6 & & 59.5 \\
\hline $2-3-140-142$ & 4.2 & 18.2 & 15.5 & 7.4 & 71.4 & 60.2 \\
\hline $2-4-15-17$ & 8.8 & 16.3 & 22.7 & 3.1 & 59.2 & 45.5 \\
\hline $2-4-40-42$ & 4.1 & 11.1 & 21.0 & 3.9 & 70.4 & 42.6 \\
\hline $2-4-65-67$ & 7.7 & 16.7 & 14.7 & 1.6 & 74.6 & 61.0 \\
\hline $2-4-90-92$ & 3.9 & 17.6 & 8.4 & 1.3 & 80.6 & 62. \\
\hline $2-4-115-11$ & 5.0 & 9.1 & 1.3 & 1.1 & 86.2 & 6.9 \\
\hline $2-4-140-1$ & 6.0 & 12.9 & 10 & & & 1. \\
\hline & & & & & & 3.3 \\
\hline & & & & & & 1. \\
\hline $2-5-65-67$ & & & & 1.3 & 82.6 & 70. \\
\hline $2-5-90-92$ & 8.3 & 16.5 & 12.7 & 5.1 & 76.9 & 72 \\
\hline $2-5-115-117$ & 7.3 & 17.1 & 13.0 & 3.4 & 74.6 & 59.2 \\
\hline $2-5-140-142$ & 7.1 & 19.3 & 15.0 & 1.4 & 66.7 & 56.8 \\
\hline $2-6-15-17$ & 7.0 & 22.8 & 28.3 & 1.9 & 73.5 & 47. \\
\hline $2-6-40-42$ & 2.9 & 16.8 & 37.8 & 0.5 & 56.5 & 7. \\
\hline $2-6-65-6$ & 18.8 & 30.0 & 12.9 & 0.0 & 69.4 & 60.2 \\
\hline $2-6-90-9$ & 11.7 & 17.3 & 6.1 & 0.0 & 84.0 & 8. \\
\hline $2-6-115-11$ & & & & 0.9 & 70.4 & 7. \\
\hline $2-6-140-142$ & 9.8 & 12.7 & 4.7 & 6.4 & 63.3 & 7 \\
\hline $2-7-15-17$ & 14.1 & 11.9 & 3.8 & 7.0 & 82.0 & 76. \\
\hline
\end{tabular}

Table 4 (continued).

Data ODP Leg 117, Hole 728A

\begin{tabular}{lrlrlll}
\multicolumn{1}{c}{ Sample } & A & B & \multicolumn{1}{c}{ C } & D & E & F \\
\hline $2-7-40-42$ & 10.5 & 14.5 & 5.4 & 5.9 & 82.0 & 71.3 \\
$3-1-15-17$ & 12.9 & 16.7 & 11.9 & 5.6 & 66.7 & 61.7 \\
$3-1-40-42$ & 3.5 & 20.8 & 7.1 & 4.9 & 83.3 & 76.3 \\
$3-1-65-67$ & 8.0 & 15.4 & 14.8 & 1.9 & 66.2 & 64.9 \\
$3-1-90-92$ & 8.5 & 14.5 & 13.8 & 5.0 & 75.8 & 68.5 \\
$3-1-115-117$ & 5.6 & - & 11.2 & - & 77.5 & 52.9 \\
$3-1-140-142$ & 5.9 & - & 22.2 & - & 75.2 & 54.1 \\
$3-2-15-17$ & 6.0 & - & 26.0 & - & 61.0 & 23.9 \\
$3-2-40-42$ & 6.3 & - & 30.2 & - & 61.0 & 35.2 \\
$3-2-65-67$ & 7.3 & - & 15.9 & - & 69.0 & 50.5 \\
$3-2-90-92$ & 10.6 & - & 14.9 & - & 66.7 & 49.0 \\
$3-2-115-117$ & 16.2 & - & 15.2 & - & 64.1 & 57.1 \\
$3-2-140-142$ & 26.7 & - & 9.4 & - & 71.4 & 44.1 \\
\hline
\end{tabular}

$\mathrm{A}=\%$ G. bulloides $(>250 \mu \mathrm{m})$

$\mathrm{B}=\%$ G. bulloides $(125-250 \mu \mathrm{m})$

$\mathrm{C}=\%$ G. menardii $(>250 \mu \mathrm{m})$

$\mathrm{D}=\% \mathrm{~N}$. pachyderma $(125-250 \mu \mathrm{m})$

$\mathrm{E}=\mathrm{W} /(\mathrm{W}+\mathrm{F}) \times 100>250 \mu \mathrm{m}$

$\mathrm{F}=\mathrm{W} /(\mathrm{W}+\mathrm{F}) \times 100125-250 \mu \mathrm{m}$

the western Arabian Sea, where the sediments are strongly influenced by the effects of the northern Indian Ocean monsoon. The location of Hole 728A is such that the effect of upwelling must be well-documented in the sedimentary record. Its proximal position on the Oman Margin also provides the possibility to study the influence of the oxygen minimum zone (OMZ) at its lower extremes. Presently, this zone extends to a water depth of $1500 \mathrm{~m}$ (Wyrtki, 1971). Since the hole is located at a water depth of about $1400 \mathrm{~m}$, small fluctuations in the OMZ may strongly affect the depositional environment.

The intensity of upwelling may be reflected in those biota that benefit from upwelling conditions, e.g., high nutrient levels. The planktonic foraminifer $G$. bulloides is known to be an indicator of upwelling (Prell and Curry, 1981; Prell, 1984b; Kroon, 1988). Relative abundance of this species reflects variations in upwelling intensity in time. Prell (1984b) successfully used this species as such in a core with a time span of $150 \mathrm{k} . \mathrm{y}$. The distribution of the various species in the sediment however, is largely affected by dissolution processes, as evidenced by the fragmentation record. Therefore, in the record studied the abundance of $G$. bulloides cannot be directly used as an indicator of upwelling.

In addition, the fragmentation record may be the result of variations in intensity, and vertical distribution of the oxygen minimum zone in time. In the OMZ, dissolution processes may affect the foraminiferal tests caused by undersaturation of calcium carbonate. During glacial periods the lower boundary of the OMZ probably was in a shallower position than during interglacial periods, when dissolution increased as a result of higher organic production. Another explanation for the increased dissolution may be the stronger influence of highly saline, oxygendepleted Red Sea and Persian Gulf bottom water outflow. Considering the latter, outflow of marginal basin bottom waters must have been severely hampered during glacial periods as a consequence of the lower sea-level stands, when sill depths were at a minimum. Considering the productivity, higher production during the interglacial periods must have occurred as a response to stronger southwestern monsoonal winds. The increase of sinking organic material leads to a stronger $\mathrm{OMZ}$ as oxygen is used to disintegrate the organic matter. This process lowers the $\mathrm{pH}$ of the water and subsequently increases calcium carbonate dissolution.

To find out which of the above-described processes caused the observed fragmentation pattern, additional information is 


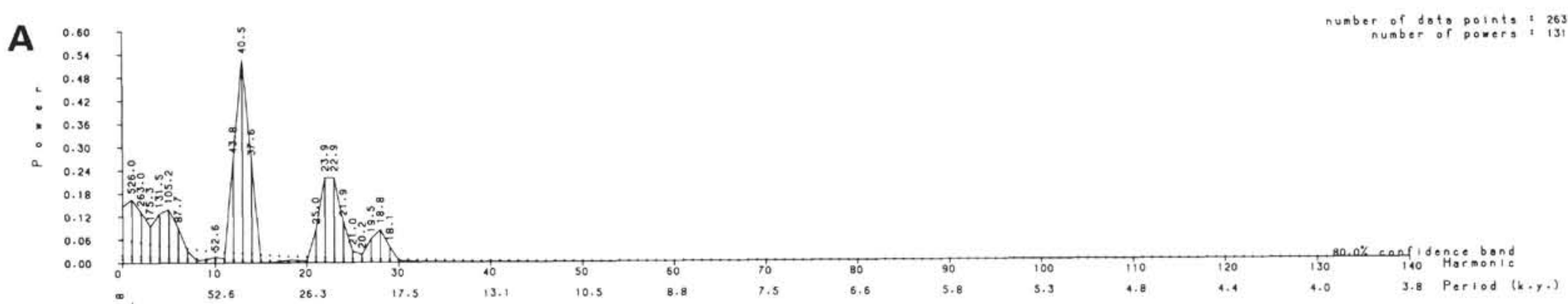

B
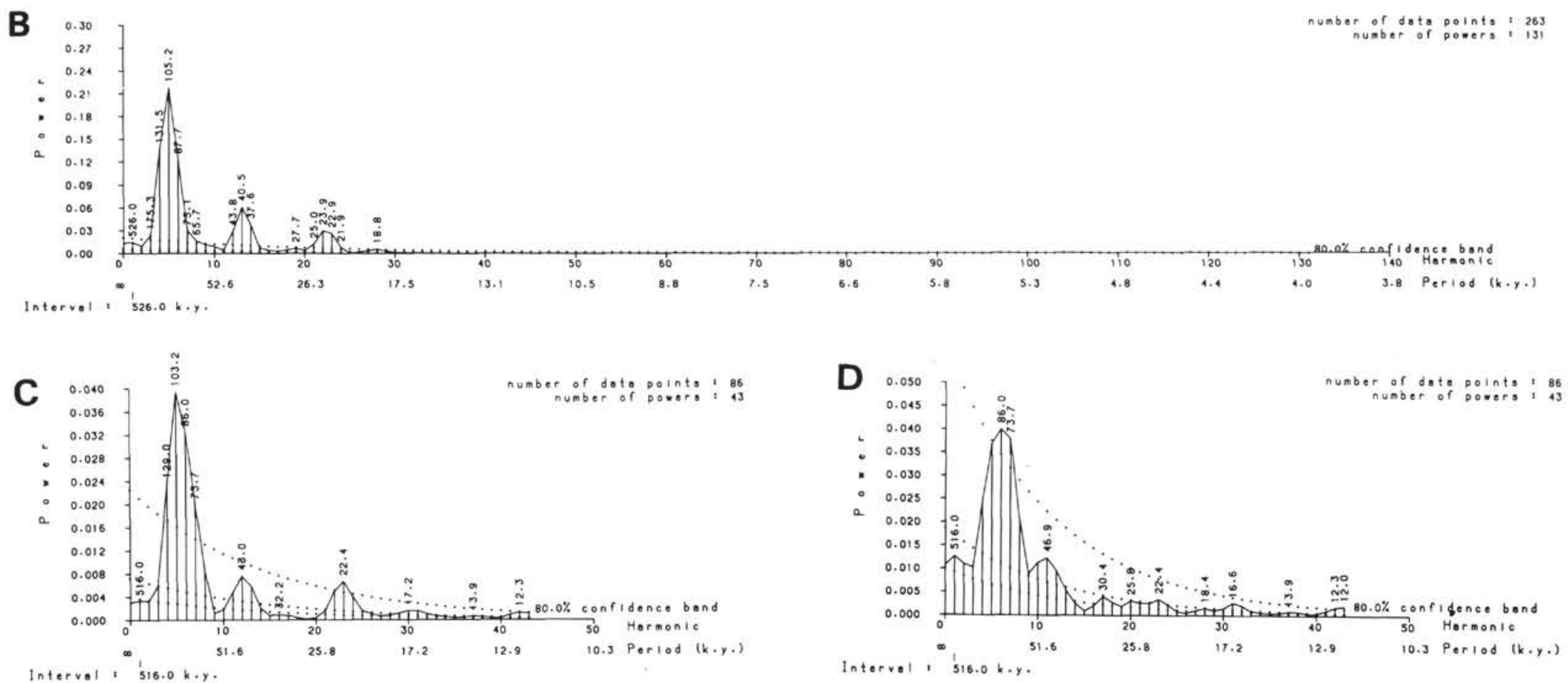

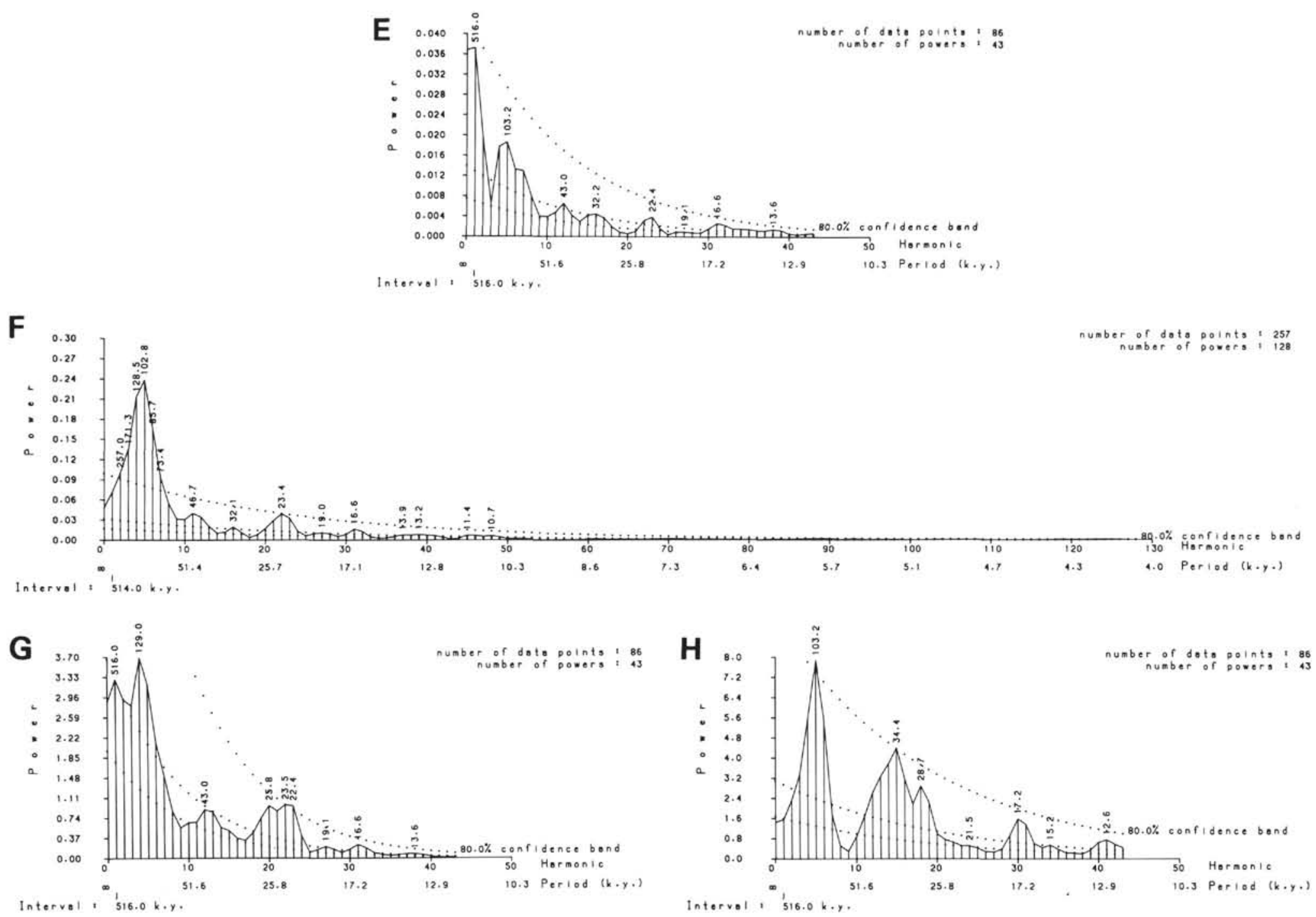

Figure 5. Discrete periodograms, based on a time interval from 12 to $524 \mathrm{k}$.y., smoothed by a Hanning filter. For comparison a first-order autoregressive process model Figure 5. Discrete periodograms, based on a time interval from 12 to together with confidence limits at the $80 \%$ level are shown. A. Summed normalized values of orbital parameters calculated at intervals of 2 k.y. B. SPEC
stacked curve calculated at intervals of $2 \mathrm{k} . y$. C. $\delta^{18} \mathrm{O}$ ratios $N$. dutertrei sampled with lag of $6 \mathrm{k} . \mathrm{y}$. D. $\delta^{18} \mathrm{O}$ ratios $G$. bulloides sampled with lag of $6 \mathrm{k} . \mathrm{y}$. E. $\delta^{18} \mathrm{O}$ ratios $G$. ruber sampled with lag of 6 k.y. F. Magnetic susceptibilities sampled with lag of 2 k.y. G. $\mathrm{CaCO}_{3}$ percentages sampled with a lag of $6 \mathrm{k}$.y. H. Foraminiferal fragmentation from the $>250 \mu \mathrm{m}$ fraction sampled with a lag of $6 \mathrm{k} . \mathrm{y}$. 

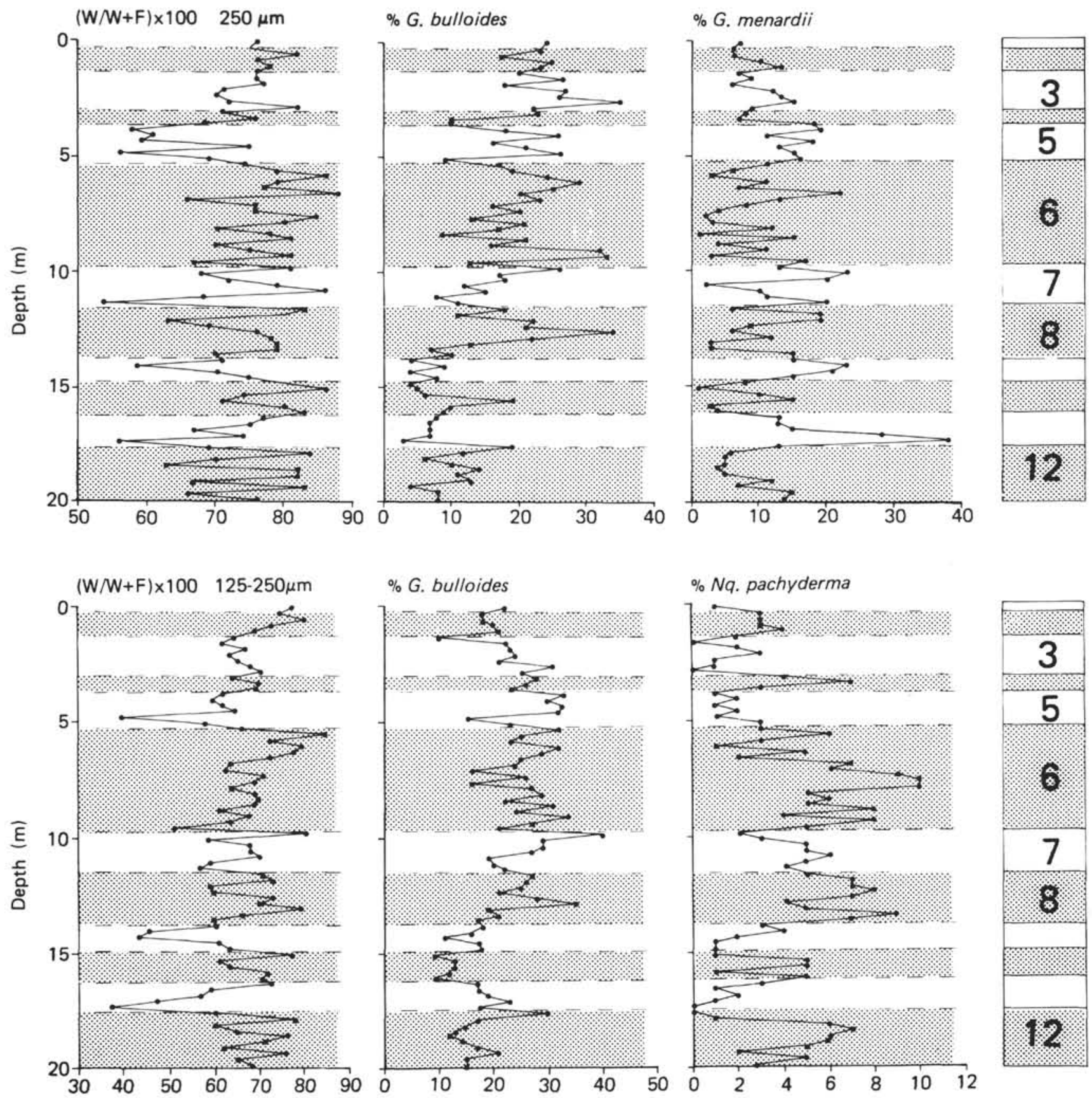

Figure 6. Preliminary results on fragmentation and species counts. Note that fragmentation has a large influence on the relative species abundances found in the sediments. During interglacial periods fragmentation is strongest and high abundances of the resistant species $G$. menardii are found, whereas relatively low abundances of $G$. bulloides are present in the samples; this species is relatively susceptible to dissolution. This fragmentation record is explained by the intensity of the $\mathrm{OMZ}$ or shallowing of the lysocline near continents as a function of enhanced productivity associated with intensified summer monsoonal winds. The relatively higher values of $N$. pachyderma during glacials may be indicative for colder seawater temperatures during these periods.

needed, e.g., a piston core transect, benthic foraminiferal species counts, and data on recent physicochemical processes occurring at the water-sediment interface in the oxygen minimum zone and at the lysocline.

Fragmentation of the foraminiferal tests implies that the southwestern monsoon was stronger during the warmer periods when summer insolation was at its maximum on the northern hemisphere. Its strength decreased during glacial periods as a consequence of albedo effects on the Tibetan Plateau (Prell, 1984a; Fontugne and Duplessy, 1986; Prell and Kutzbach, 1987; Shimmield et al., this volume; ten Haven and Kroon, this volume).

Shallowing of the lysocline near continents may be another possibility which explains the dissolution of carbonate during interglacial periods as a function of increased upwelling and concomitant productivity (Berger, 1970). 


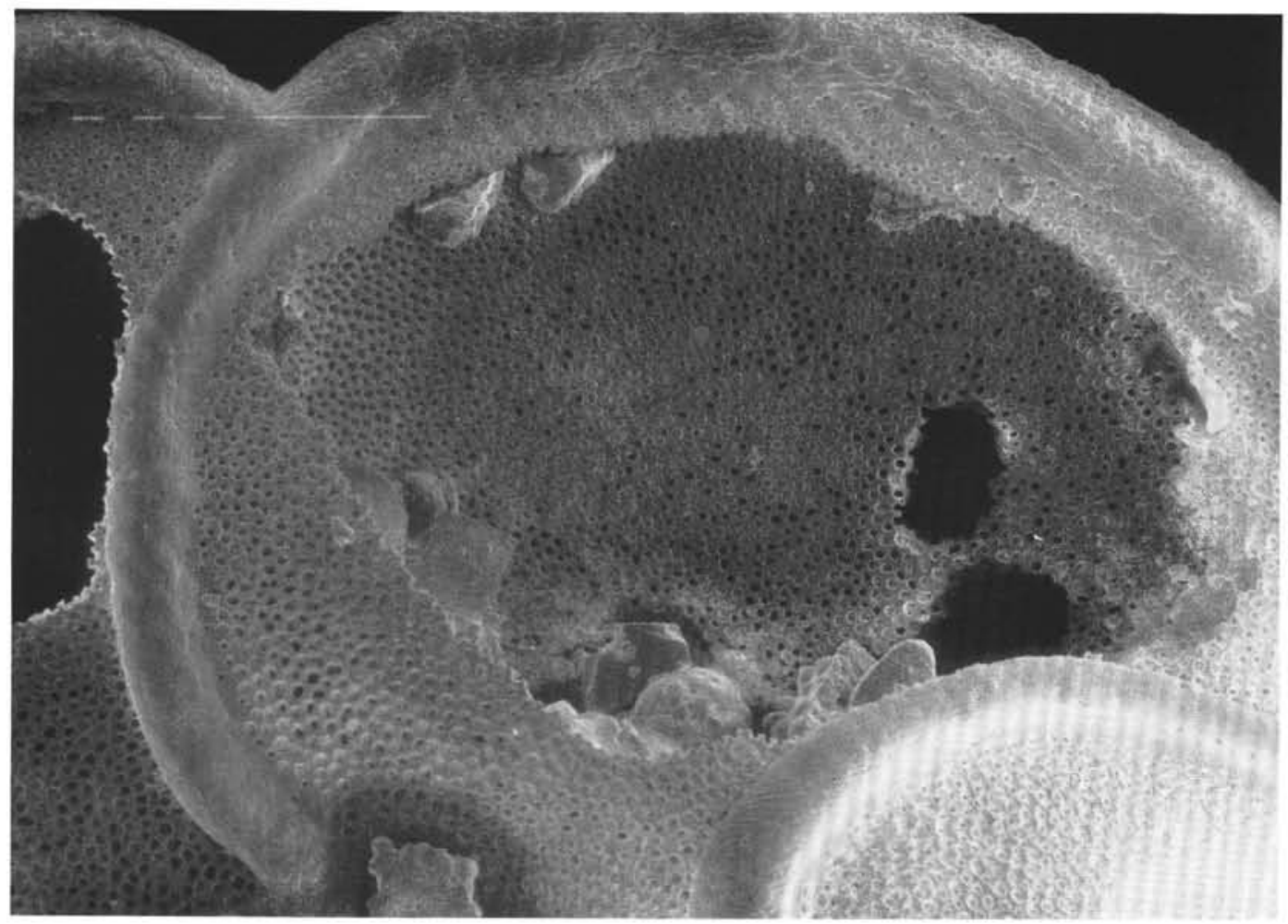

Figure 7. Part of G. menardii from Sample 2-6-40/42, isotopic stage 13, showing that fragmentation is caused by dissolution rather than by mechanical breakdown.

\section{ACKNOWLEDGMENTS}

We thank Jan E. van Hinte for critically reviewing the first draft of the manuscript, Gerald Ganssen for his advice on stable isotope matters and making laboratory facilities available to us, Peter de Menocal for kindly providing us with the magnetic susceptibility data, and Saskia Kars for her technical assistance. We are grateful to Peter Willekes, Roel van Elsas, and Martin Koonert who performed the calcium carbonate determinations and prepared many washed residues. This study has been carried out as a part of ODP Leg 117 and was supported by the "Nederlandse Organisatie voor Wetenschappelijk Onderzoek" (first and second author, grant 751-356-018) and the "Stichting Onderzoek der Zee" (SOZ). This is a publication of the Geomarine Centre Amsterdam.

\section{REFERENCES}

Berger, A. L., 1978. A simple algorithm to compute long term variations of daily or monthly insolation. Louvain-la-Neuve: Université catholique. Contrib. Inst. Astron. Géophys. G. Lemaitre, 18:1-48.

Berger, A., and Pestiaux, P., 1984. Accuracy and stability of the Quaternary terrestrial insolation. In Berger, A. L., Imbrie, J., Hayse, J., Kukla, G., and Saltzman, B. (Eds.). Milankovitch and Climate (Pt. 1): Dordrecht (D. Reidel), 83-111.

Berger, W. H., 1970. Planktonic foraminifera: selective solution and the lysocline. Mar. Geol., 8:111-138.

Bruce, J. G., 1974. Some details of upwelling off the Somali and Arabian coasts. J. Mar. Res., 32:419-423.

Craig, H., 1957. Isotopic standards for carbon and oxygen correction factors for mass spectrometric analysis of $\mathrm{CO}_{2}$. Geochim. Cosmochim. Acta, 12:133-149.

Currie, R. I., Fisher, A. E., and Hargraves, P. M., 1973. Arabian Sea upwelling. In Zeitzschel, B., and Gerlach, S. A. (Eds.), The Biology of the Indian Ocean (Vol. 3): New York (Springer-Verlag), 37-52.

Fontugne, M. R., and Duplessy, J. C., 1986. Variations of the monsoon regime during the Upper Quaternary: evidence from carbon isotopic record of organic matter in the North Indian Ocean sediment cores. Palaeogeogr. Palaeoclimatol. Palaeoecol., 56:69-88.

Hastenrath, S., and Lamb, P. J., 1979. Climatic Atlas of the Indian Ocean: Madison, WI (Univ. of Wisconsin Press).

Imbrie, J., Hays, J. D., Martinson, D. G., McIntyre, A., Mix, A. C., Morley, J. J., Pisias, N. G., Prell, W. L., and Shackleton, N. J., 1984. The orbital theory of Pleistocene climate: support from a revised chronology of the marine delta $\delta^{18} \mathrm{O}$ record. In Berger, A., Imbrie, J., Hays, J., Kukla, G., and Saltzman, B. (Eds.), Milankovitch and Climate (Pt. 1): Dordrecht (D. Reidel), 269-305.

Kroon, D., 1988. Distribution of extant planktic foraminiferal assemblages in Red Sea and northern Indian Ocean surface waters. In Brummer, G.J.A., and Kroon, D. (Eds.), Planktonic Foraminifers as Tracers of Ocean-Climate History: Amsterdam (Free Univ. Press), 229-270.

Kroon, D., and Ganssen, G., 1989. Northern Indian Ocean upwelling cells and the stable isotope composition of living planktonic foraminifers. Deep-Sea Res. Part A, 36:1219-1236.

Mountain, G. S., and Prell, W. L., 1989. Geophysical reconnaissance survey for ODP Leg 117 in the northwest Indian Ocean. In Prell, W. L., Niitsuma, N., et al., Proc. ODP, Init. Repts., 117: College Station, TX (Ocean Drilling Program), 51-64.

Peterson, L. C., and Prell, W. L., 1985. Carbonate preservation and rates of climatic change: an $800 \mathrm{kyr}$ record from the Indian Ocean. In Sundquist, E. T., and Broecker, W. S. (Eds.), The Carbon Cycle and Atmospheric $\mathrm{CO}_{2}:$ Natural Variations Archean to Present: Am. Geophys. Union Monogr., 32:251-270.

Pisias, N. G., and Moore, T. C., Jr., 1981. The evolution of Pleistocene climate: a time series approach. Earth Planet. Sci. Lett., 52:450456.

Prell, W. L., 1982. Oxygen and carbon isotope stratigraphy for the Quaternary of Hole 502B: evidence for two modes of isotopic variability. In Prell, W. L., Gardner, J. V., et al., Init. Repts. DSDP, 68: Washington (U.S. Govt. Printing Office), 455-464.

1984a. Monsoonal climate of the Arabian Sea during the late Quaternary: a response to changing solar radiation. In Berger, A. L., Imbrie, J., Hays, J., Kukla, G., and Saltzman, B. (Eds.). Milankovitch and Climate (Pt. 1): Dordrecht (D. Reidel), 349-366. 
1984b. Variation of monsoonal upwelling: a response to changing solar radiation. In Hansen, J. E., and Takahashi, T. (Eds.), Climatic Processes and Climate Sensitivity. Am. Geophys. Union, Maurice Ewing Ser., 29:48-57.

Prell, W. L., and Curry, W. B., 1981. Faunal and isotopic indices of monsoonal upwelling: western Arabian Sea. Oceanol. Acta, 4:9198.

Prell, W. L., Imbrie, J., Martinson, D. G., Morley, J. J., Pisias, N. G., Shackleton, N. J., and Streeter, H. F., 1986. Graphic correlation of oxygen isotope stratigraphy application to the late Quaternary. Paleoceanography, 1:137-162.

Prell, W. L., and Kutzbach, J. E., 1987. Monsoon variability over the past 150,000 years. J. Geophys. Res., 92:8411-8425.

Shackleton, N. J., and Opdyke, N. D., 1973. Oxygen isotope and palaeomagnetic stratigraphy of Equatorial Pacific core V28-238: oxygen isotope temperatures and ice volumes on a $10^{5}$ year and $10^{6}$ year scale. Quat. Res., 3:39-55.

Shipboard Scientific Party, 1989a. Explanatory notes. In Prell, W. L., Niitsuma, N., et al., Proc. ODP, Init. Repts., 117: College Station, TX (Ocean Drilling Program), 11-34.

1989b. Introduction, background, and major objectives for ODP Leg 117 (western Arabian Sea) in search of ancient monsoons. In Prell, W. L., Niitsuma, N., et al., Proc. ODP, Init. Repts., 117: College Station, TX (Ocean Drilling Program), 5-10. 1989c. Site 728. In Prell, W. L., Niitsuma, N., et al., Proc. ODP, Init. Repts., 117: College Station, TX (Ocean Drilling Program), 495-546.

Sirocko, F., and Sarnthein, M., 1989. Wind-borne deposits in the northwest Indian Ocean: record of Holocene sediments versus modern satellite data. In Leinen, M., and Sarnthein, M. (Eds.), Paleoclimatology and Paleometeorology: Modern and Past Patterns of Global Atmospheric Transport. NATO ASI Ser., 401-433.

Sprenger, A., and ten Kate, W. G., 1990. A graphical software system to present stratigraphic information of surveyed sections. Comput. Geosci.

ten Kate, W. G., and Sprenger, A., 1989. On the periodicity in a calcilutite-marl succession (SE Spain). Cretaceous Res., 10:1-31.

Wyrtki, K., 1971. Oceanographic Atlas of the International Ocean Expedition: Washington (Nat. Sci. Found.).

1973. Physical oceanography of the Indian Ocean. In Zeitschel, B., and Gerlach, S. A. (Eds.), The Biology of the Indian Ocean (Vol. 3): New York (Springer-Verlag), 18-36.

Date of initial receipt: 4 October 1989

Date of acceptance: 25 July 1990

Ms 117B-167 